Endocrinol. Japon., Vol. 5, No. 4 (1958)

\title{
STUDIES ON UROPAROTIN
}

\section{ALUMINA GOLUMN CHROMATOGRAPHY ON HUMAN AND RABBIT UROPAROTIN}

\author{
YOSOJI ITO \\ Department of Physiological Chemistry, Faculty of \\ Pharmaceutical Sciences, University of Tokyo \\ MASAAKI YAMAMOTO \\ Research Laboratory, Teikoku Hormone \\ Mfg. Co. Ltd., Kawasaki
}

It has been previously reported that the purified U.P. possessing remarkable Ca-reduction activity and circulating leucocyte effect in rabbit with dosage $1 \mathrm{mg}$ per $\mathrm{kg}$ is obtained by ethanol fractionation of the crude U.P. prepared from human urine by isoelectric precipitation. Further investigation led to the finding that Parotin-like substance exists in normal rabbit urine. This substance was extracted and purified by the same method as that of human U.P., and was found to have a twice stronger activity than human U.P.

In order to obtain homogeneous substances with further purification of these U.P., column chromatography was tried. At first, the adsorption affinities of U.P. to various adsorbents, such as non-ionic, anionic, and cationic exchanger, were detected, and it was found that alumina was the most suitable one. Then, a remarkable purifying effect was observed with alumina column chromatography and highly purified U.P. could be obtained easily in good yield.

\section{MATERIALS AND METHOD}

\begin{abstract}
Materials
The material used in this experiment was obtained from human and rabbit urine by the ethanol fractionation which has been reported in a previous paper, and the purified U.P. was termed as (FE). The yields from urine were $14 \mathrm{mg}$ per 1. with human FE and $22 \mathrm{mg}$ per 1 . with rabbit FE. Ca-activities were $1.0 \mathrm{mg}$ per $\mathrm{kg}$ with human $\mathrm{FE}$ and $0.5 \mathrm{mg}$ per $\mathrm{kg}$ with rabbit FE.

The affinity of $F E$ on various adsorbents

The following adsorbents were examined; hyflo-super-cel and cellulose powder as non-ionic exchanger, oxycellulose, XE-64 and C.M.-cellulose as cationic exchanger, alumina, acidic alumina,
\end{abstract}

Received for publication October 11, 1958. 
Dowex-2, and DEAE-cellulose as anionic exchanger. C.M.-cellulose was prepared from cellulose and monochloroacetic acid, and DEAE-cellulose was from cellulose and diethylaminoethylchloride by Peterson and Sober (1956) method.

Acidic-alumina was obtained with excellent anion exchanging effect from alumina after treatment under HCl.

These adsorbents were buffered with $\mathrm{pH} 5.02,0.01 M$ acetate-buffer and $\mathrm{pH} 6.85,0.01 M$ phosphate-buffer before adding to a $0.1 \% \mathrm{FE}$ solution. The affinities of $\mathrm{FE}$ on adsorbents were compared to each other by the batch method; every solution was stirred for some time and centrifuged to measure the contents of non-adsorbed protein in supernatant fluid. The weight percentage of FE adsorbed directly was estimated by these non-adsorbed protein contents.

Alumina chromatogram procedure

Two kinds of column size, $1.2 \times 30 \mathrm{~cm}$ and $2.2 \times 40 \mathrm{~cm}$, were used. Previously, alumina was stirred, left and decantated with distilled water for several times, and fine particles were removed. It was suspended in distilled water or in the buffer first used, and sufficiently equilibrated, then compacted into the column. The sample was dissolved in the same water or buffer, applied in the column, then the column was washed until the equilibration was gained.

The following buffers were used as eluents such as; (1) $\mathrm{pH} 5.0,0.1 M$ ammonium acetate buffer, (2) $\mathrm{pH} 5.0,0.1 \mathrm{M}$ sodium phosphate buffer, (3) $\mathrm{pH} 6.80$ dist. water, (4) $\mathrm{pH} 5.0,0.1 M$ sodium phosphate buffer, (5) $\mathrm{pH} 6.80,0.1 M$ sodium phosphate buffer, (6) $\mathrm{pH} 6.80,0.1 M$ ammonium acetate and (7) $\mathrm{pH} 8.85,0.1 \mathrm{M}$ disodium phosphate. Among these buffers, the most suitable ones were chosen for each experiment. Effluents were taken every 3 or $10 \mathrm{cc}$ with fraction collector, and each fraction was measured of its protein content by the photoelectric method at $277 \mathrm{~m} \mu$. The effluents which show an adsorption peak were collected together and precipitated with ethanol. The obtained precipitate was removed and lyophilized.

Bioassay

The biological activity was estimated by serum Ca-reduction method and circulating leucocyte reaction method which have already been described in the previous paper. And hereafter, a biological effect which decrease the calcium level in rabbit was termed as "Ca-activity" and another biological effect which is reactive to the number of circulating leucocytcs was termed as "L-activity".

Measurement of isoelectric-point by paper electrophoresis

In order to correct the influence of electro-osmotic flow which occurred in the paper itself, non-charged dextran was dissolved in the same buffer solution used to the sample, to make an $8 \%$ concentration, and the dextran and sample were moved together on a paper. The experimental conditions in various $\mathrm{pH}$ were made as constantly as possible. In this experiment, veronal-sodium veronal buffer ( $\mathrm{pH}$ 8.6), acetic acid-sodium acetate buffer ( $\mathrm{pH} 5.0$ and 4.0), glycine-hydrochloride buffer ( $\mathrm{pH} 3.0,2.5$ and 2.0) were tried as the buffer, and $\mathrm{NaCl}$ was added to make 0.5 ionic strength in order to prevent precipitation in the buffer of lower salt concentration. After electrophoresis the paper was heated and fixed. The dextran part was coloured with acidic ethanol solution of B.P.B., and the sample part was coloured with acidic aq. solution of B.P.B. and the electrophoretic patterns were obtained.

\section{EXPERIMENTAL RESULTS AND DISCUSSIONS}

\section{Adsorption affinity of $F E$}

The adsorption affinities of $\mathrm{FE}$ to various adsorbents at $\mathrm{pH} 6.85$ and $\mathrm{pH} 5.02$ are shown in Figure 1; FE was scarcely adsorbed to cationic exchangers and adsorbed selectively to anionic exchangers. In non-ionic exchangers, a considerable affinity at a lower $\mathrm{pH}$ was observed, but almost nothing at a higher $\mathrm{pH}$. Among anionic 
$\mathrm{pH} 5.02$

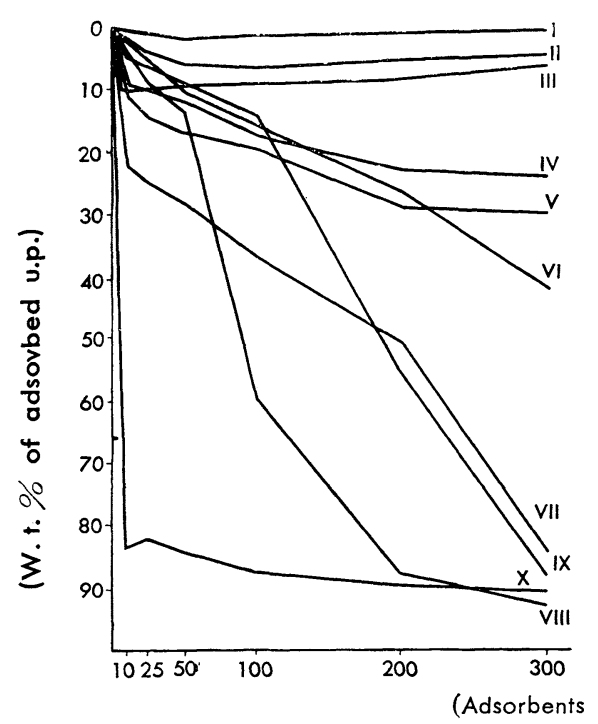

$\mathrm{pH} 6.85$

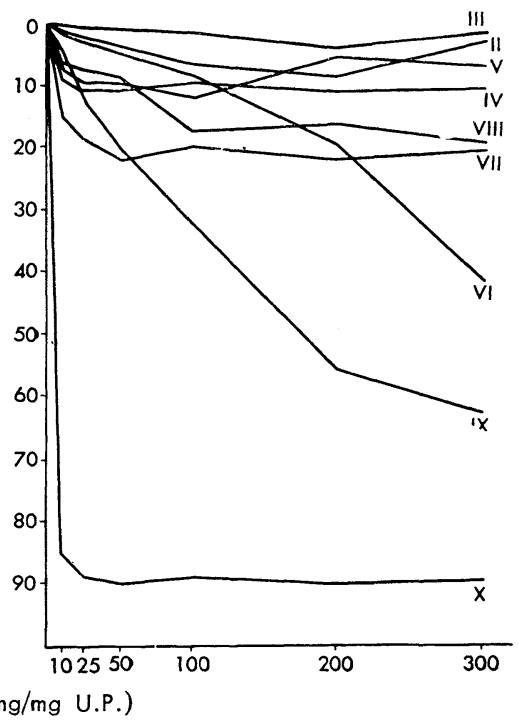

Fig. 1. Adsorptive affinities of FE on various adsorbentes.

(I): Oxycellulose (II): C.M.-cellulose (III): XE-64 (IV): Cellulose (V): Hyflo-Super-Cel (VI): Dowex-2 (VII): Alumina (VIII): Acid alumina (IX): XE-58 (X): DEAE-cellulose

exchangers, DEAE-cellulose exhibited the most potential effect at both pHs. Since the characteristics in the affinity on adsorbent and in the elution are required in column chromatogram, it is desirable to use an adsorbent whose adsorbing effect is so variable under the condition as alumina. Thus, alumina was used as the adsorbent in the following experiments.

Column chromatography in a small scale

The diagram of effluents under the condition of various $\mathrm{pH}$ of $0.1 M$ phosphate buffer is shown in Figure 2; the human U.P. was adsorbed completely at $\mathrm{pH} 5.00$ (I) and then more alkaline buffers were tried to obtain effluents, in which two bands at $\mathrm{pH} 6.80$ (II) and one band at $\mathrm{pH} 8.85$ (III) were observed, respectively. As for Ca-activity, the first band $\left(\mathrm{AC}_{1}\right)$ eluted at $\mathrm{pH} 6.80$ had the strongest activity, $(250 \mathrm{\gamma} / \mathrm{kg})$. When considering recovery-activity, all activity seemed to be concentrated in this band. On the other hand, when the acetate buffer was tried instead of phosphate buffer, another diagram was obtained shown in Figure 2; complete adsorption, however, was observed at $\mathrm{pH} 5.00\left(\mathrm{I}^{\prime}\right)$ and it was similar to the adsorption occurring when phosphate buffer was used, but even when the $\mathrm{pH}$ of acetate buffer was raised to $6.80\left(\mathrm{II}^{\prime}\right)$ no effluent appeared and complete adsorption was still observed. Then, the band of effluent was obtained after the column was eluted with phosphate buffer of the same $\mathrm{pH}\left(\mathrm{III}^{\prime}\right)$ instead of acetate buffer, and its biological activity was concentrated into the first band $\left(\mathrm{BC}_{1}\right)$ as well as the result of phosphate buffer chromatography. Thereupon, there was a significant difference between acetate and phosphate buffer, and this difference 


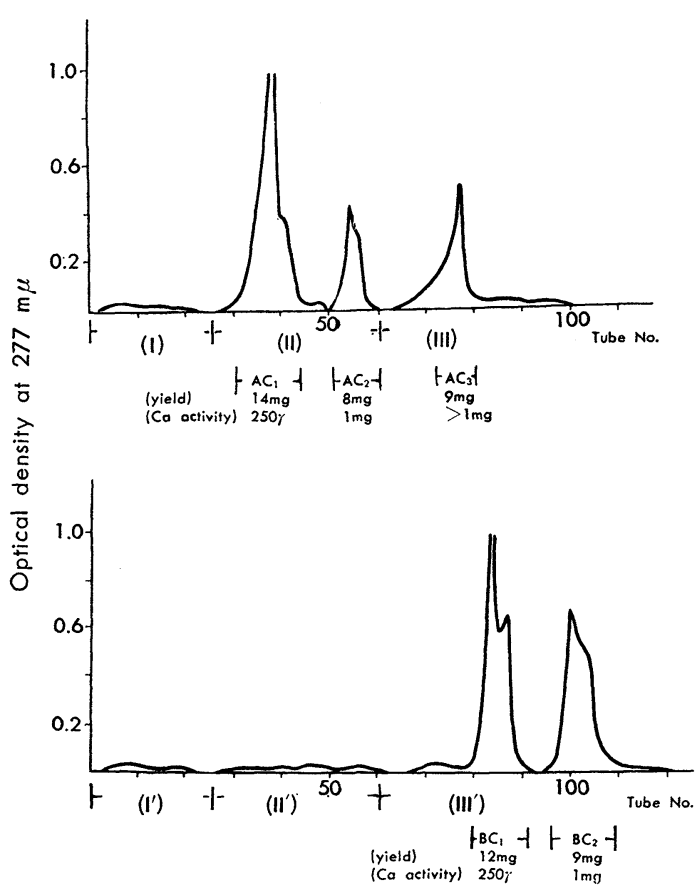

Fig. 2. Chromatography of human FE on alumina column

(upper part): $50 \mathrm{mg}$ of human FE was applied on $1.2 \times 30 \mathrm{~cm}$ column.

Eluents: (I) $0.1 \mathrm{M} \mathrm{pH} 5.0$ phosphate buffer

(II) $0.1 \mathrm{M} \mathrm{pH} 6.8$ phosphate buffer

(III) $0.1 \mathrm{M} \mathrm{pH} 8.85$ disodium phosphate

(lower part): $50 \mathrm{mg}$ of human FE was applied on $1.2 \times 30 \mathrm{~cm}$ column.

Eluents: (I) $0.1 \mathrm{M} \mathrm{pH} 5.0$ acetate buffer

(II) $0.1 \mathrm{M} \mathrm{pH} 6.80$ ammonium acetate

(III) $0.1 \mathrm{M} \mathrm{pH} 6.80$ phosphate buffer
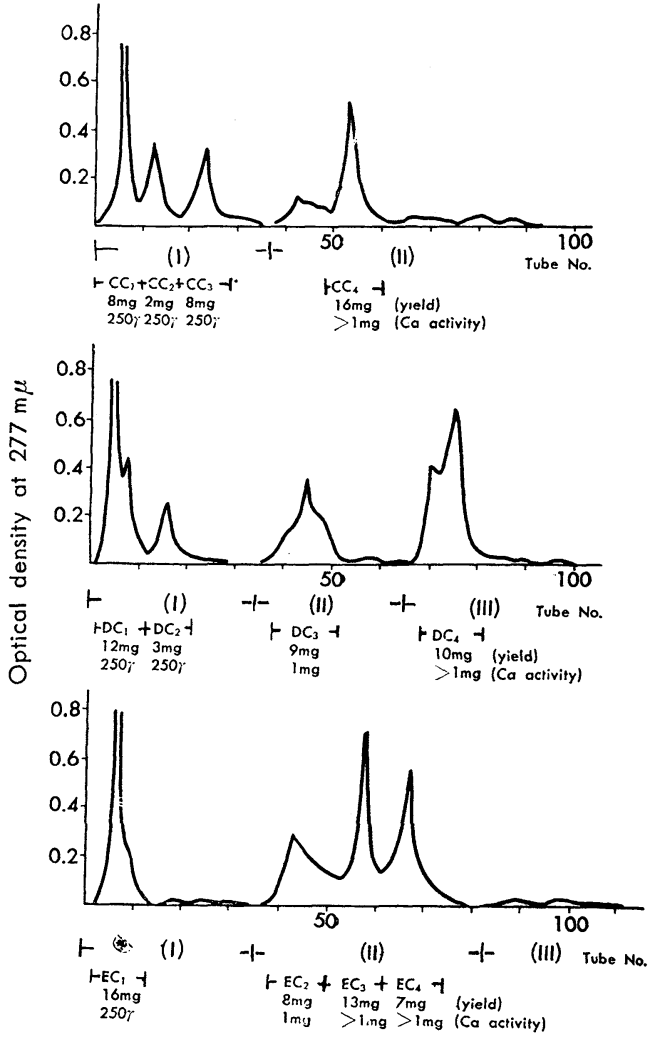

Fig. 3. Chromatography of human FE on alumina column

In all experiments, $50 \mathrm{mg}$ of human $\mathrm{FE}$ were applied on $1.2 \times 30 \mathrm{~cm}$ column.

Eluents: (upper part)

(I) $0.1 \mathrm{M} \mathrm{pH} 6.80$ phosphate buffer

(II) $0.1 \mathrm{M} \mathrm{pH} 8.85$ disodium phosphate (middle part)

(I) $0.01 \mathrm{M} \mathrm{pH} 6.80$ phosphate buffer

(II) $0.1 \mathrm{M} \mathrm{pH} 6.80$ phosphate buffer

(lower part)

(III) $0.1 \mathrm{M} \mathrm{pH} 8.85$ disodium phosphate

(I') $\mathrm{pH} 6.80$ distilled water

(II') $0.1 \mathrm{M} \mathrm{pH} 6.80$ phosphate buffer

(III') $0.1 \mathrm{M} \mathrm{pH} 8.85$ disodium phosphate

seemed to be due to each specific property against alumina.

As the specific elution of U.P. with phosphate buffer at $\mathrm{pH} 6.80$ had been observed, the influence of ion-concentration in phosphate buffer $(\mathrm{pH} \mathrm{6.80)}$ on the pattern of elution diagram was studied as the next step. Under the condition of $0.1 M$ and $\mathrm{pH}$ 6.80, three bands appeared and each band contained more active principle, whereas, the activity was distributed in these three bands $\left(\mathbf{C G}_{1}, \mathrm{CG}_{2}\right.$, $\left.\mathrm{CC}_{3}\right)$, and the following band $\left(\mathrm{CG}_{4}\right)$ was eluted at $\mathrm{pH} 8.85$ and was found to be inactive (Upper part in Fig. 3). Then, with $0.01 M$ and at $\mathrm{pH} 6.80$, two bands 
were eluted, whereas the biological activity was distributed into both bands and the purificational effect was observed $\left(\mathrm{DC}_{1}, \mathrm{DC}_{2}\right)$ and moreover, after this elution, other conditions were tried to obtain more bands; as the result, one band $\left(\mathrm{DC}_{3}\right)$ with $0.1 \mathrm{M}$, at $\mathrm{pH} 6.80$, and another band $\left(\mathrm{DC}_{4}\right)$ with $0.1 \mathrm{M}$, at $\mathrm{pH} 8.85$ appeared but both patterns were found to be useless for purification (middle part in Fig. 3).

When the chromatography, however, was tried by elution with distilled water at $\mathrm{pH} 6.80$ for the purpose of keeping its inoic concentration at a more lower condition, the biologically active material was eluted to form nearly single band, and the lower active materials were eluled with the solvent of higher ionic concentration $(0.1 M)$ to form three bands $\left(\mathrm{EC}_{2}, \mathrm{EC}_{3}, \mathrm{EC}_{4}\right.$, ) (lower part in Fig. 3). From these results, it may be considerable that the diagram is apt to form a single band

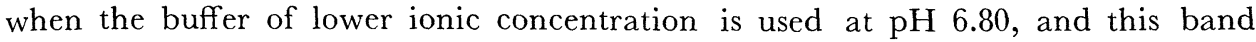
is easily separated from other biologically lower active parts, and especially, a remarkable effect is obtained when distilled water was used.

A preparative column chromatography of human FE in a large scale and a chromatography of rabbit U.P.

The method of column chromatography with phosphate buffer at $\mathrm{pH} 6.80$ was so easy to prepare and so effective in purifying the human U.P. with good recovery, that this method was put to preparative use in a large scale, and at the same time, a similar experiment was tried on rabbit U.P.

The method of large scaled column chromatography was as follows; after the large scaled column was compacted with alumina, the sample dissolved in distilled water was applied to this column and then was eluted with distilled water at $\mathrm{pH} 6.80$. The result was quite similar to the diagram which was obtained with small scaled column; elution bands $\left(\mathrm{FC}_{1}, \mathrm{FC}_{2}, \mathrm{FC}_{3}\right.$, $\mathrm{FC}_{4}$ ) were obtained (Fig. 4). The results of biological screening test of these bands are shown in Table 1 and Table 2; on the human U.P., the strongest activity was obtained from band $\mathrm{FG}_{1}$, in all experiments, and almost all activity was concentrated into this band, so that, the yield from urine was 3-5 mg per 1. and the Ca-activity was constantly $250 \gamma$ per $\mathrm{kg}$, and moreover, its recovery-activity was $50-100 \%$ and about four times increase in activity was obtained. On the rabbit U.P., $\mathrm{GC}_{1}$ corresponded to human $\mathrm{FG}_{1}$

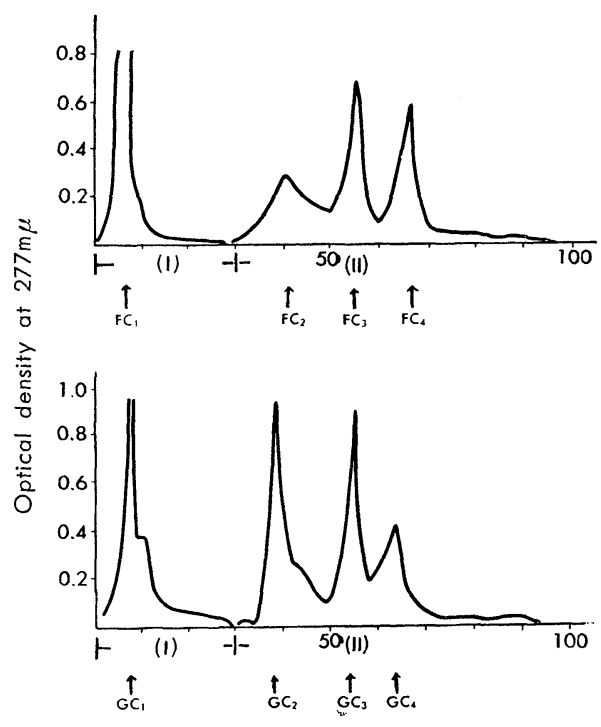

Fig. 4. Preparative chromatography of human FE and chromatography of rabbit FE on alumina column.

(Upper part) $300 \mathrm{mg}$ of human FE was applied on $2.2 \times 40 \mathrm{~cm}$ column.

Eluents: (I) $\mathrm{pH} 6.80$ distilled water (II) $0.1 \mathrm{M} \mathrm{pH} 6.80$ phosphate buffer

(Lower part) $50 \mathrm{mg}$ of rabbit FE was applied on $1.2 \times 30 \mathrm{~cm}$ column.

Eluents: (I) $\mathrm{pH} 6.80$ distilled water (II) $0.1 \mathrm{M} \mathrm{pH} 6.80$ phosphate buffer 
Table 1. The results of preparative chromatography of human FE

\begin{tabular}{|c|c|c|c|c|}
\hline Exp. & Fraction & Yield $(\%)$ & $\begin{array}{c}\text { Yield } \\
\mathrm{mg} / \mathrm{l} \text {. Urine }\end{array}$ & Ca-activity \\
\hline \multirow{3}{*}{1} & $\mathrm{FC}_{1}$ & 22.5 & 3.5 & $250 \gamma$ \\
\hline & $\begin{array}{l}\mathrm{C}_{2} \\
\mathrm{C}_{3}\end{array}$ & $\begin{array}{l}11.0 \\
18.1\end{array}$ & & $\begin{array}{r}1 \mathrm{mg} \\
>1 \mathrm{mg}\end{array}$ \\
\hline & $\mathrm{C}_{4}$ & 8.9 & & $>1 \mathrm{mg}$ \\
\hline \multirow{3}{*}{ II } & $\mathrm{FC}_{1}$ & 28.0 & 5.0 & $250 \gamma$ \\
\hline & $\begin{array}{l}\mathrm{C}_{2} \\
\mathrm{C}_{3}\end{array}$ & $\begin{array}{l}13.4 \\
15.6\end{array}$ & & 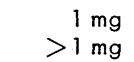 \\
\hline & $\mathrm{C}_{4}$ & 7.2 & & $>1 \mathrm{mg}$ \\
\hline \multirow{3}{*}{ III } & $\mathrm{FC}_{1}$ & 23.5 & 4.2 & $100 \gamma$ \\
\hline & $\begin{array}{l}\mathrm{C}_{2} \\
\mathrm{C}_{3}\end{array}$ & $\begin{array}{r}9.2 \\
13.4\end{array}$ & & $\begin{array}{l}500 \gamma \\
>1 \mathrm{mg}\end{array}$ \\
\hline & $\mathrm{C}_{4}$ & 7.3 & & $>1 \mathrm{mg}$ \\
\hline \multirow{3}{*}{ IV } & $\mathrm{FC}_{1}$ & 24.0 & 4.3 & $250 \gamma$ \\
\hline & $\begin{array}{l}\mathrm{C}_{2} \\
\mathrm{C}_{3}\end{array}$ & $\begin{array}{l}15.6 \\
17.6\end{array}$ & & $\begin{aligned} & 1 \mathrm{mg} \\
> & 1 \mathrm{mg}\end{aligned}$ \\
\hline & $\mathrm{C}_{4}$ & 6.8 & & $>1 \mathrm{mg}$ \\
\hline
\end{tabular}

Table 2. The results of chromatography of rabbit FE

\begin{tabular}{ccccc}
\hline \hline Exp. & Fraction & Yield $(\%)$ & $\begin{array}{c}\text { Yield } \\
\mathrm{mg} / \mathrm{l} \text {. urine }\end{array}$ & Ca-activity \\
\hline \multirow{3}{*}{$\mathrm{K}-1$} & $\mathrm{GC}_{1}$ & 29.5 & 6.0 & $100 \mathrm{\gamma}$ \\
& $\mathrm{C}_{2}$ & 27.5 & & $1 \mathrm{mg}$ \\
& $\mathrm{C}_{3}$ & 13.0 & & $1 \mathrm{mg}$ \\
& $\mathrm{C}_{4}$ & 3.2 & 5.4 & $100 \mathrm{\gamma}$ \\
$\mathrm{K}-11$ & $\mathrm{GC}_{1}$ & 24.6 & & $1 \mathrm{mg}$ \\
& $\mathrm{C}_{2}$ & 21.8 & $\mathrm{mg}$ \\
\hline
\end{tabular}

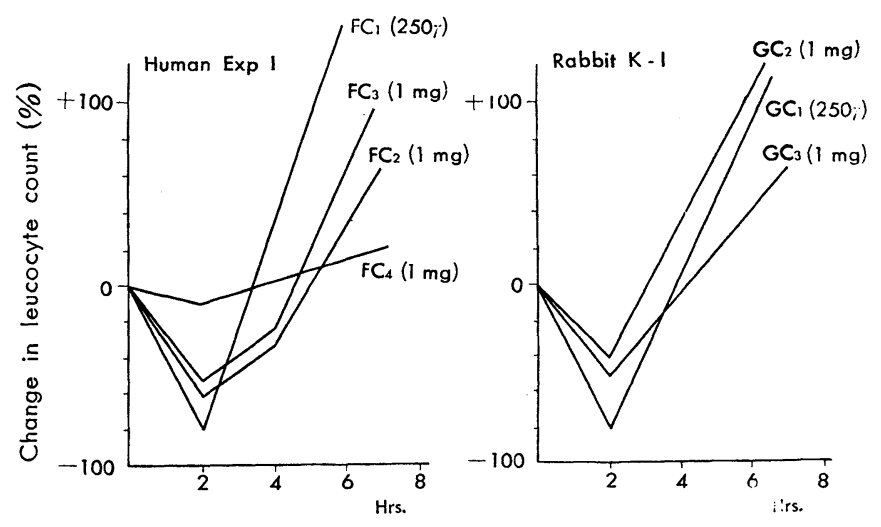

Fig. 5. Effect of fractions obtained by alumina column chromatography on the leucocytes in rabbits. 
in two experiments; 5-6 mg per 1. in the yield from urine, $100 \gamma$ per $\mathrm{kg}$ in the Ca-activity which increases about 5 times in activity, and $50-100 \%$ recoveryactivity was estimated. As for L-activity, the strongest activities were observed in $\mathrm{FC}_{1}$ of human U.P. and in $\mathrm{GC}_{1}$ of rabbit U.P. and both biological activities (namely Ca-activity and L-activity) were parallel with one another (Fig. 5).

Further step for purifying human $F C_{1}$

In order to obtain a more purified material, further chromatographical development was tried on $\mathrm{FC}_{1}$ which had been obtained by the method described above; the material was applied on the small scaled column of alumina to be adsorbed with $0.1 M$ acetate buffer at $\mathrm{pH}$ 5.00. And then, it was eluted with $0.1 M$ phosphate buffer. The result is shown in Figure 6 ; the $\mathrm{FC}_{1}$ which had been observed as a single band in the previous method was eluted by this method to form two bands $\left(\mathrm{HC}_{1}, \mathrm{HC}_{2}\right)$. According to the results of the bioassays (Ca-, and L-activity), two-fold increase in both biological activities, was observed with $\mathrm{HC}_{1}$ (Fig. 7); the recoveryactivity of $\mathrm{HC}_{1}$ was about $50 \%$ and the yield from urine was $1.0-1.2 \mathrm{mg}$ per 1. As the considerable part of activity still remained in $\mathrm{HC}_{2}$, it may not be suitable to recognize this method as the best, but this method may be valuable in obtaining a stronger active U.P.

The paper-electrophoresis and the ultracentrifuge of $H C_{1}$

Paper-electrophoresis and ultracentrifuge were used analytically to estimate the chemical purity of $\mathrm{HC}_{1}$ which was the most purified material obtained by the above described chromatography, and the result is shown in Figure 8. According to the result of paper electrophoresis, this material seemed to be homogeneous, but slight contamination was observed with the pattern of ultracentrifuge (Fig. 9.), so that one could not consider the material as chemically homogenous.

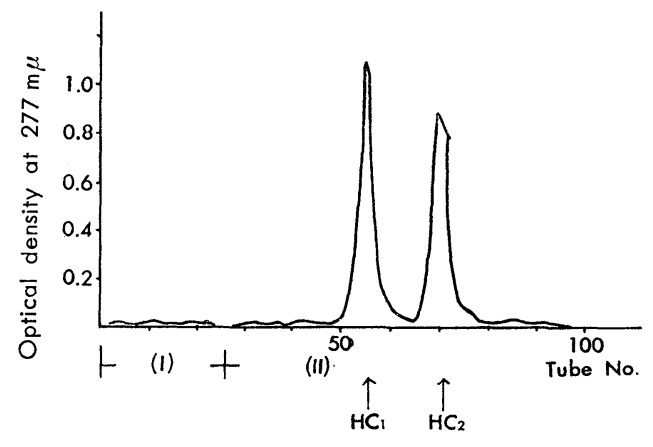

Fig. 6. Further chromatography of human $\mathrm{FC}_{1}$ on alumina column. $50 \mathrm{mg}$ of human $\mathrm{FC}_{1}$ was applied on $1.2 \times 30 \mathrm{~cm}$ column.

Eluents: (I) $0.1 \mathrm{M} \mathrm{pH} 5.0$ acetare buffer (II) $0.1 \mathrm{M} \mathrm{pH} 6.80$ phosphate buffer

Yield and $\mathrm{Ca}$ activity

\begin{tabular}{crrrr}
\hline Exp. No. Eraction yield $(\%)$ & $\begin{array}{l}\text { yield } \\
\mathrm{mg} / \mathrm{L} \text { urine }\end{array}$ & Ca actirity \\
\hline 1 & $\mathrm{HC}_{1}$ & 26.0 & 1.0 & $100 \gamma$ \\
& $\mathrm{C}_{2}$ & 34.0 & - & $250 \mathrm{\prime \prime}$ \\
\hline $\mathrm{H}$ & $\mathrm{HC}_{1}$ & 32.0 & 1.2 & $100 "$ \\
& $\mathrm{C}_{2}$ & 16.0 & - & $250 "$ \\
\hline
\end{tabular}

L-activity

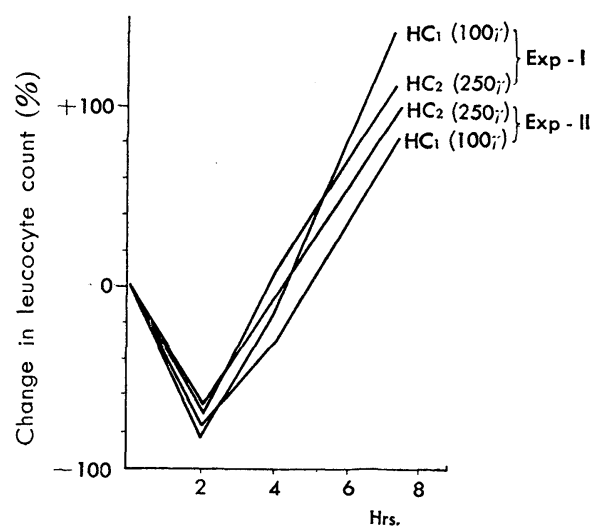

Fig. 7. Yields and activities of fractions obtained by further chromatography. 


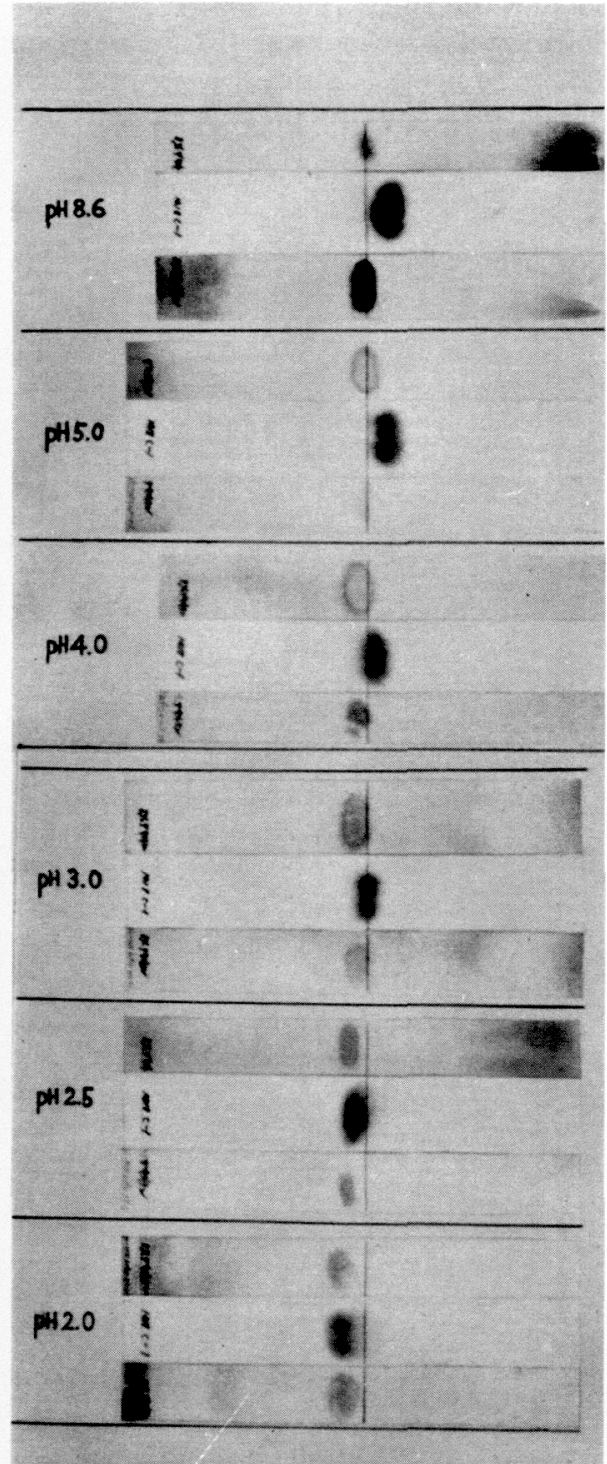

Fig. 10. Paper electrophoresis of $\mathrm{HC}_{1}$ under various $\mathrm{pH}$.

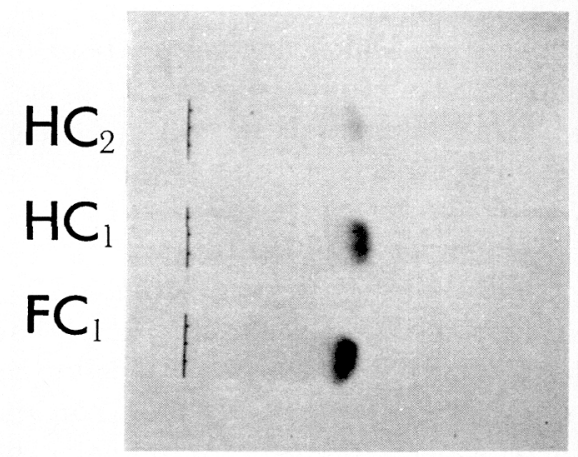

Fig. 8. Paper electrophoresis of fracctions obtained by further chromatography.

Veronal buffer, $\mathrm{pH}$ 8.6, $\mu=0.1,1 \mathrm{~mA} / \mathrm{cm}, 6$ hrs.

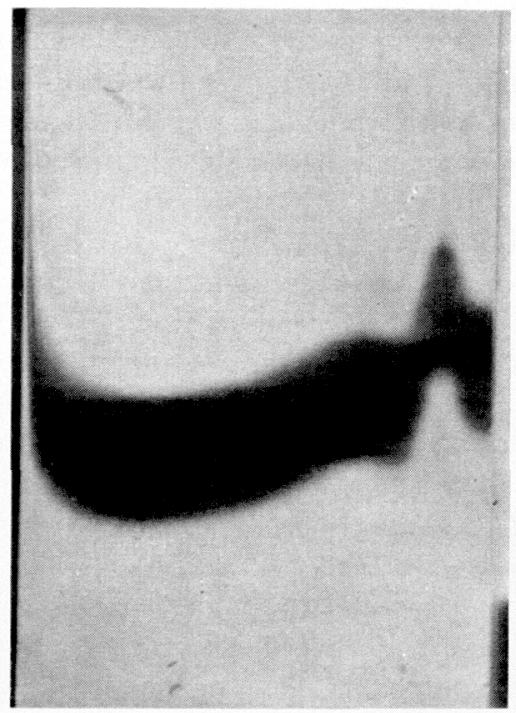

Fig. 9. Ultracentrifuge of $\mathrm{HC}_{1}$ pH 7.8 phosphate buffer, 59,789 r.p.m. 30 mins.

\section{Isoelectric point}

$\mathrm{HC}_{1}$ was selected as a sample to estimate the isoelectric point, and paper electrophoresis was tried under the condition of various $\mathrm{pH}$, using dextran as a control material. The result is shown in Figure 10. The distance of migration of $\mathrm{HC}_{1}$, corrected by dextran, was plotted against $\mathrm{pH}$ to obtain Figure 11 . As the result, the isoelectric point of $\mathrm{HC}_{1}$ was estimated as $\mathrm{pH}$ 2.3. As previously des- 


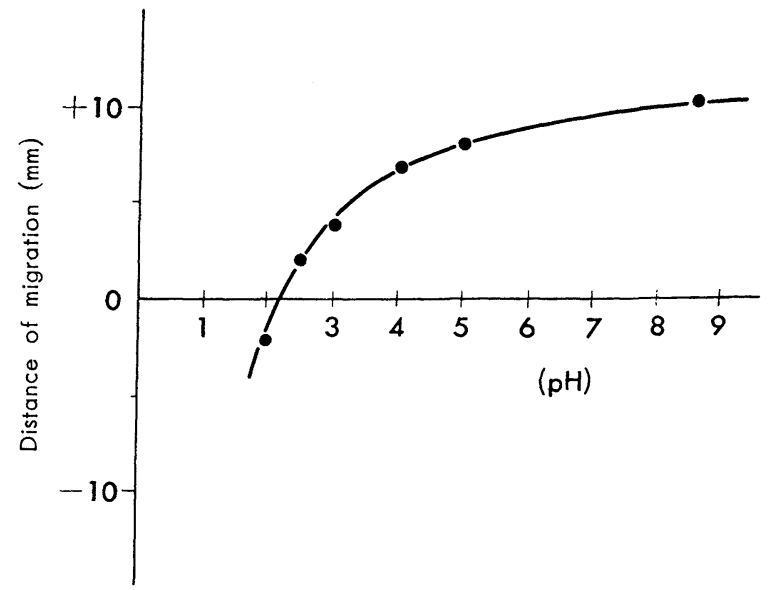

Fig. 11. Migrations of $\mathrm{HC}_{1}$ under various $\mathrm{pH}$.

cribed, the experiment was performed with the buffer solution of high salt concentration because of the solubility of U.P., and so, some experimental error could be eliminated, but the lower isoelectric point than one of Parotin was observed. As the result, U.P. is preferable to be classified as an acid-protein.

\section{SUMMARY}

U.P. was purified easily by alumina column chromatography to obtain the highly purified preparation in good yield. In human U.P., a preparation whose activity was $100 \gamma$ per $\mathrm{kg}$, was obtained with the yield of $1.0-1.2 \mathrm{mg}$ per 1 . and in rabbit U.P., a preparation was obtained, whose estimated values were $100 \gamma$ per $\mathrm{kg}$ as the activity, and 5-6 mg per 1 . as the yield. It was, however, observed that even with the most purified active preparation of human U.P., the chemical homogeneity was not obtained; slight contamination with any other component was observed with ultracentrifugical pattern. The isoelectric point of human U.P. was estimated as $\mathrm{pH} 2.3$ by using buffer solution $(\mu=0.5)$, and acid-proteinlike properties were observed.

\section{ACKNOWLEDGEMENT}

The authors wish to express their gratitude to Miss Yoshiko Ishida for her cooperation during the course of this study.

\section{REFERENGE}

Peterson, E. A. and H. A. Sober (1956). J. Am. Chem. Soc. 78, 751. 